A form with flowers of various colors is:-

Hydrangea serrata f. rosalba Wilson, n. comb.

Hydrangea japonica Siebold \& Zuccarini, Fl. Jap. I. 106 (1840), in part.Lindley in Bot. Reg. xxx. t. 61 (1844).-Paxton, Mag. Bot. xir. 199, t. (1846).-Bean, Trees \& Shrubs Brit. Isl. I. 626 (1914).

Hydrangea japonica rosalba Van Houtte in Fl. des Serr. xvi. 75, tt. 1649-50 (1865-66).-Carrière in Rev. Hort. 1866, 432, t.-Regel in Gartenfl. xv. 290 (1866).

Hydrangea japonica $\beta$. Lindleyi Regel in Gartenfl. xv. 289 (1866).

Hydrangea opuloides $\alpha$. roseo-alba Dippel, Handb. Laubholzk. III. 324 (1893).

Hydrangea Hortensis var. Lindleyana Nicholson in Garden, XLVI. 466 (1894).

Hydrangea Lindleyana Nicholson in Garden, XLvi. t. 990 (1894).

Hydrangea hortensis var. rosalba Rehder in Bailey, Cycl. Am. Hort. II. 785 (1900).

Hydrangea opuloides var. Lindleyana Rehder in Bailey, Stand. Cycl. Hort. III. 1621 (1915).

Hydrangea opuloides var. rosalba Rehder in Mitt. Deutsch. Dendr. Ges. xxiv. 220 (1915).

Cultivated: Arnold Arboretum (Nos. 516, 516-1, 517, 517-1, 521, 521-1, 522-1, 2210-1, 2442, 2444); Hort. Bot. Gard. Washington, A. Rehder, June 27, 1900; Hort. Kew, G. Nicholson, Nos. 1777, 1784, 1789, July 19, 1880; Hort. Bot. Gard. Kiel, B. Graef, No. 3557, 1897. Japan; Hort. Sakurai, K. Sakurai, May 12, 1906; Tokyo, K. Miyabe, June 10, 1882.

In this form the leaves are somewhat pubescent on the underside and on the upper surface of the midrib especially at the base, and vary in shape from obovate to ovate-elliptic. The sterile ray-flowers may be white or pink or in fading may change from one color to the other. The petaloid sepals may be deeply or sparingly toothed, or they may be entire. It is a variable and very common form and is often cultivated under the erroneous name of $H$. japonica. There are also very many garden forms of this plant; indeed, most of them which have been raised in France and have dull green leaves have been derived from it; such is $H$. "Impératrice Eugénie" Carrière in Rev. Hort. 1868, 469, t.

A form with numerous sterile flowers is:

Hydrangea serrata var. stellata Wilson, n. comb.

Hydrangea Sitsitan Siebold in Nov. Act. Acad. Leop.-Carol. xIv. pt. 2, 692 (Syn. Hydrang.) (1829).-De Candolle, Prodr. Iv. 666 (1830).

Hydrangea stellata Siebold \& Zuccarini, Fl. Jap. I. 112, t. 59 (1840).-Regel in Gartenfl. xv. 291 (1866).-Bean, Trees \& Shrubs Brit. Isl. I. 626 (1914).

Hydrangea stellata $\beta$. prolifera Regel in Gartenfl. xv. 291, t. 521 (1866).Nicholson, Dict. Gard. II. 163 (1887).

Hydrangea Hortensia $\eta$. stellata Maximowicz in Mém. Acad. Sci. St. Pétersb., sér. 7, x. no. xvi. 14 (Rev. Hydrang. As. Or.) (1867).-Hemsley in Garden x. $266(1876)$.

Hydrangea Hortensis 3. stellata Franchet \& Savatier, Enum. Pl. Jap. I. 152 (1875).

Hydrangea opuloides h. stellata Dippel, Handb. Laubholzk. III. 324 (1893).-Schneider, Ill. Handb. Laubholzk. I. 392 (1905).--Matsumura, Ind. Pl. Jap. II. pt. 2, 180 (1912).--Rehder in Bailey Stand. Cycl. Hort. III. 1622 (1915).

Hydrangea opuloides var. prolifera Rehder in Bailey, Stand. Cycl. Hort. III. $1622(1915)$.

This is a sterile form with numerous petaloid sepals, pink rose or white in color and ovate to lanceolate in shape. Siebold records it as cultivated 
round Kyoto. It is in fact a common plant in Japanese gardens where according to Matsumura it is known as Shichidankwa. There are a number of garden forms cultivated of which "fimbriata" and "rubroplena" are examples. There seems no good reason for keeping Regel's f. prolifera distinct from the type.

In Thunberg's Herbarium the specimen named Viburnum serratum $\alpha$. represents the var. stellata but I do not think that this specimen should be considered the type since Thunberg does not cite under his description any particular specimen and since the majority of them belong to the form here considered the typical $H$. serrata DC.

\section{NEW SPECIES, VARIETIES AND COMBINATIONS FROM THE HERBARIUM AND THE COLLECTIONS OF THE ARNOLD ARBORETUM ${ }^{1}$}

\section{Alfred Rehder}

Sinowilsonia Henryi Hemsley in Hooker's Icon. xxıx. t. 2817 (1906).--Rehder \& Wilson in Sargent, Pl. Wilson. I. 429 (1913).

Descriptioni adde: Flores monoeci, proterandri, racemosi; racemi terminales, masculi et feminei plerique in ramis distinctis; racemi masculi praecoces, e gemmis aphyllis terminalibus orti, pedunculo brevi $5-8 \mathrm{~mm}$. longo incluso 4-6 cm. longi, penduli, multiflori, densi; rhachis sparse fusco-stellato-pilosa; flores apetali et sine ullo vestigio ovarii, bracteati bracteis lineari-subulatis pedicellum paullo superantibus sparse fuscostellato pilosis a basi pedicelli plerisque plus minusve remotis; pedicelli sparsissime stellato-pilosi, $1.5-3 \mathrm{~mm}$. longi, bracteolis 2 lateralibus bracteis simillimis sed brevioribus plerisque circa medium insertis instructi; sepala 5, lineari-spathulata, 3-4 mm. longa, antheras vix vel paullo superantia, dorso apicem versus dense fusco-stellato-pilosa, post anthesin recurva, plus minusve irregulariter inserta et non stricte verticillata; stamina 5, episepala, filamentis brevissimis basi sepalorum adnatis, antheris anguste ovalibus $2.5 \mathrm{~mm}$. longis apiculatis rimis lateralibus dehiscentibus: racemi feminei densi, sub anthesi in plante nostra $1.5-2.5 \mathrm{~cm}$. longi, demum multo elongati; flores cum stigmatibus inclusis $5 \mathrm{~mm}$. longi; calycis tubus sub anthesi 1.5 longus et ovarium paullo tantum superans; sepala $2 \mathrm{~mm}$. longa; stigmata violacea.

The flowering for the first time in this Arboretum of Sinowilsonia Henryi offered an opportunity to study the hitherto unknown staminate flowers, which, as the description shows, are greatly simplified in their structure. The flowers are arranged in catkin-like racemes very similar in appearance to those of some Amentaceae, particularly to certain Poplars. The whole floral structure appears more or less irregular; the bracts are inserted,

\footnotetext{
${ }^{1}$ Continued from p. 116.
} 
usually considerably below the pedicel to which they belong and appear therefore irregularly scattered between the pedicels along the rhachis; the anthers and the sepals before anthesis are nearly or quite of the same length and are inserted approximately at the same height, but during anthesis the axis lengthens and disarranges the floral whorls which become thus more or less racemose. The tendency at the same time of the parts to assume an unilateral position and the absence of any vestige of an ovary makes the similarity of the inflorescence to that of Populus still greater. The staminate flowers of Sinowilsonia certainly show greater approach to a primitive structure than those of any of the related genera and in the catkin-like shape of the inflorescence resemble the incompletely known staminate flowers of Fortunearia (see Rehder \& Wilson in Sargent, Pl. Wilson. I. 428) which, however, have at least a rudimentary ovary. The much elongated calyx-tube of the pistillate flower, as described and figured by Hemsley, represents the state as it appears some time after anthesis. During anthesis it is not much longer than the ovary, but it begins to lengthen afterwards, as the growing flowers on our living plant have shown.

Tilia platyphyllos var. rubra, comb. nov.

T. europaea 5. rubra Weston, Bot. Univ. I. 298 (1770).

T. europaea $\beta$. corallina Aiton, Hort. Kew. II. 229 (1789).

?T. rubra De Candolle, Cat. Pl. Monspel. 150 (1813); Prodr. I. 513 (1825), in part.

T. corallina Smith in Rees, Cycl. xxxv. no. 2 (1819).-Bosc in Encycl. Méth. Agric. vir. 748 (1821).

T. rubra G. Don, Gen. Syst. I. 553 (1831), in part.-Kirchner in Petzold \& Kirchner, Arb. Musc. 155 (1864), in part.

T. mollis var. corallina Spach in Ann. Sci. Nat. sér. 2, II. 338 (1834).

T. grandifolia $\gamma$. rubella Ortmann in Flora, xvin. 502 (1835).

T. platyphyllos var. corallina Hartwig \& Ruempler, Bäume \& Sträuch. 570 (1875).-Dippel, Handb. Laubholzk. III. 61 (1893), in part.

T. grandifolia corallina C. Koch ${ }^{1}$ apud Beissner, Schelle \& Zabel, Handb. Laubholz-Ben. 339 (1903).

The oldest varietal name for this form is apparently rubra, based on $T$. europaea var. rubra Weston. This is identical, at least in part, with $T$. rubra G. Don, and probably also with T. rubra De Candolle, Cat. Pl. Monspel. 150 (1813), and Prodr. I. 513 (1825), a name applied by many authors to an entirely different species; a few remarks about this and $T$. corinthiaca Bosc may not be out of place here.

Tilia rubra was described by De Candolle in 1813 as intermediate between $T$. microphylla (=T. cordata Mill.) and T. platyphyllos and he stated that it was first separated by Bosc from these two European species and that it is commonly cultivated as a shade tree under the names "Tilleul a bois rouge," "Tilleul de Corinthe;" from the latter name he assumes that it was introduced from Greece. These remarks seem to

${ }^{1} \mathrm{~K}$. Koch did not publish this combination; in 1853 (Hort. Dendr. 50) he cites $T$. europaea var. corallina Ait. as a synonym of T. rubra and in 1869 (Dendr. I. 472) he mentions T. europaea corallina among the forms of T. platyphyllos without making a varietal combination. 
indicate that De Candolle as well as Bose had in mind the hybrid between $T$. cordata and T. platyphyllos described the same year as $T$. vulgaris Hayne (T. hybrida Bechstein, a form or synonym of T. vulgaris, was first described and figured by Bechstein in 1819 in his Forstbot. ed. 3, 1463, tab. 4, not in 1810 as quoted by Schneider, and not by Behlen in ed. 5 as quoted in Index Kewensis), but the description of the under side of the leaves, the petioles and the branchlets as "pilosiuscula" and of the bark of the branches as red may be taken to indicate that the authors had before them a form of T. platyphyllos and probably the var. rubra. Bosc himself in 1821 refers his "Tilleul de Corinthe" to $T$. corallina (in Encycl. Méth. Agric. vir. 748) and Spach (in Ann. Sci. Nat. sér. 2, II. 337 [1834]) refers both names as synonyms to his T. mollis ( $=T$. platyphyllos). In 1825 De Candolle gives "Tauria" as the habitat of T. rubra and cites a specimen collected by Steven without changing the description from that of 1813. This is not identical with T. rubra of Simonkai and of later authors which I refer to $T$. dasystyla Stev. (T. begoniifolia Stev., T. multiflora Ledeb., T. caucasica Rupr.), nor is it the T. corinthiaca of Simonkai (in Mat. Term. Közl. Mag. Tud. Akad. xxı. 330 [1888] ); the characters of these two species do not agree with the descriptions given by Bosc and De Candolle and it is very unlikely that any of them were in cultivation at that time, while Bosc states that his "Tilleul de Corinthe" has been in cultivation since time immemorial. In regard to T. corinthiaca Bosc it should be stated that the name did not originate with Bosc who calls it "Tilleul de Corinthe" (in Nouv. Cours Agric. xir. 139 [1809] and in ed. 2. xxirl. 406 [1823|). Who first latinized Bose's name I cannot say with certainty; I find it first mentioned by De Candolle in 1824 (Prodr. 1. 513) as a synonym of his T. rubra for which he gives "Tauria" as the native country. This would leave without a name the form occurring in Greece and distinguished by Simonkai as $T$. corinthiaca Bosc, but I doubt if it is specifically distinct from T. dasystyla Stev.

Helianthemum nummularium var. cupreum Schneid. f. crocatum, comb. nov.

H. hyssopifolium $\alpha$. crocatum Sweet, Cist. 29, t. (1825-30).

H. chamaecistus var. §. cupreum Grosser in Engler, Pflanzenr. IV-193, 84 (1903), in part, as to synon. $\alpha$. crocatum.

H. vulgare var. crocatum Bean, Trees \& Shrubs Brit. Isl. I. 617 (1914).

This form differs from var. cupreum only in its saffron-yellow flowers more or less suffused with a ferrugineus or coppery tint.

As Janchen has shown (in Oesterr. Bot. Zeitschr. Lvirl. 406-413 [1908]) the correct name according to the International Rules of the Sun Rose usually called Helianthemum chamaecistus Mill. or H. vulgare Gaertn. is H. nummularium Mill. based on Cistus nummularius L. Janchen, however, distinguishes besides $H$. nummularium the following species: $H$. hirsutum Mérat, $H$. nitidum Clementi, $H$. tomentosum Spreng. and H. grandiflorum Lam. \& DC. which all seem to be connected by intermediate forms and are best considered varieties or subspecies of $H$. nummularium. Most of 
the resulting new combinations have been already made by C. Schneider (Ill. Handb. Laubholzk. II. 351-352, 1909), but a few forms not unfrequently met with in gardens, as the one cited above and the following, were not mentioned by him.

Helianthemum nummularium var. mutabile, comb. nov.

Cistus mutabilis Jacquin, Misc. II. 340 (1781); Icon. Pl. Rar. I. 10, t. 99 (1781-86).

Helianthemum mutabile Persoon, Syn. Ir. 79 (1807).-Guimpel, Otto \& Hayne, Abb. Fremd. Holzart. 56, t. 46 (1819-1825). - Sweet, Cist. 106, t (1825-30).

H. vulgare var. e. mutabile Willkomm, Icon. Descript. Pl. II. 116 (1856).

H. chamaecistus var. \&. mutabile Grosser in Engler, Pflanzenr. IV-163, 86 (1903).

This variety has the leaves sparingly pilose above or nearly glabrous and gray-tomentose beneath. The sepals are reddish and villose on the ribs and glabrous between them; the petals are pale rose or sometimes variegated with white.

Helianthemum nummularium var. stramineum, comb. nov.

H. stramineum Sweet, Cist. 93, t. (1825-30).

H. chamaecistus var. ל. stramineum Grosser in Engler, Pflanzenr. IV-163, 86 (1903).

H. vulgare var. stramineum Bean, Trees \& Shrubs Brit. Isl. I. 617 (1914).

This variety has the leaves green and pilose above, whitish tomentose beneath, flat or scarcely revolute at the margins; the sepals are nearly glabrous and the petals sulphur-yellow with a darker yellow blotch at base.

Helianthemum nummularium var. venustum, comb. nov.

H. venustum Sweet, Cist. 10, t. (1825-30).

H. mutabile var. canescens (Sweet) K. Koch, Hort. Dendr. 37 (1853), in part.

H. chamaecistus var. o. venustum Grosser in Engler, Pflanzenr. IV-163, 86 (1903).

H. vulgare var. venustum Bean, Trees \& Shrubs Brit. Isl. I. 617 (1914).

This variety has purplish branchlets and the leaves glabrescent and lustrous above, whitish tomentose beneath; the sepals are stellate-puberulous, the petals rather large and crimson with a yellow blotch at base.

Helianthemum nummularium var. diversifolium, comb. nov.

H. diversifolium Sweet, Cist. 95, t. (1825-30).

H. mutabile Pers. $\gamma$. diversifolium K. Koch. Hort. Dendr. 37 (1853).

H. chamaecistus var. $\eta$. diversifolium Grosser in Engler, Pflanzenr. Iv-163, 86 (1903).

This variety has the leaves hirsute above and whitish tomentose beneath, the upper ones linear-lanceolate, acute and revolute at the margin, the lower ones oval, obtuse and flat. The sepals are pilose, and the petals are red with a darker blotch at the base.

Helianthemum nummularium var. diversifolium f. rubro-plenum, nom. nov.

$H$. diversifolium $\beta$. multiplex Sweet, Cist. 98, t. (1825-30).

H. mutabile 8. multiplex K. Koch, Hort. Dendr. 37 (1853).

H. vulgare var. diversifolium multiplex Bean, Trees \& Shrubs Brit. Isl. I. 617 (1914), not $H$. nummularium var. tomentosum f. multiplex Schneid.

This is a form with double flowers of the preceding variety. 
Hedera nepalensis K. Koch var. sinensis, comb. nov.

H. Helix Hance in Jour. Bot. xx. 6 (1882).-Hemsley in Jour. Linn. Soc. xxin. 343 (1888), as to the Chinese plant.-Harms in Bot. Jahrb. xxix. 487 (1900).-Pavolini in Nuov. Giorn. Bot. Ital. n. ser. xv. 418 (1908).Pampanini in Nuov. Giorn. Bot. Ital. n. ser. xvir. 678 (1910); xvir. 130 (1911).-Hayata, Fl. Mont. Formos. 110 (1910); Icon. Pl. Formos. II. 62 (1912).-Diels in Not. Bot. Gard. Edinburgh, vil. 258, 288 (1912).Léveillé, Fl. Kouy-Teheou, 34 (1914).

H. himalaica var. sinensis Tobler, Gatt. Hedera, 79, figs. 39-42 (1912).

H. himalaica Harms \& Rehder in Sargent, Pl. Wilson. II. 555 (1916), in part.

The difference between the Himalayan and the Chinese plant is quite marked in the leaves of the sterile branches which are more or less pinnately lobed with 2-5 lobes or coarse teeth on each side in the Himalayan plant and only 3-lobed in the Chinese plant, but otherwise the two forms show little difference except that the leaves are generally narrower and longer in the Himalayan plant. In the pinnately lobed leaves of the sterile branches the typical $H$. nepalensis differs from all other species and forms of Hedera, and none of the numerous specimens of the Chinese form in the Arboretum Herbarium show any tendency toward pinnate lobing, the leaves of the sterile shoots having never more than two small basal lobes.

When Tobler proposed his $H$. himalaica he overlooked the fact that in $1853 \mathrm{~K}$. Koch (Hort. Dendr. 284) had already given the name H. nepalensis to this species basing it on the H. Helix of Don's Prodromus and Roxburgh's Flora Indica.

Rhododendron carolinianum var. album, comb. nov.

Rhododendron punctatum var. album Kelsey, Wholesale Trade List Hardy Am. Pl. 1895-96, 10 (1895), nomen.-Hort. apud Rehder, in Bailey Cycl. Am. Hort. Iv. 1523 (1902),--Rehder apud Schneider, Ill. Handb. Laubholzk. II. 374 (1909).

Rhododendron carolinianum Margarettae Ashe in Rhodora, xxIII. 177 (1921).

This form differs from typical $R$. carolinianum Rehd. chiefly in the white color of the flowers and in the leaves which are as a rule larger and narrower and more pointed, even short-acuminate at the apex. According to Ashe (1. c.) it is common in North Carolina along the Blue Ridge at an altitude of between 1500 and $4000 \mathrm{ft}$. in McDowell and Buncombe Counties, and it has also been found in Rutherford, Polk and Henderson Counties, to which may be added Haywood County according to a specimen in this herbarium collected by H. D. House (No. 4563) on Fork Ridge, at $4500 \mathrm{ft}$. altitude. Ashe states that the white-flowered form has a definite range and is not found together with the typical rose-purple form which occurs at altitudes above $4000 \mathrm{ft}$. The white-flowered form was first introduced into gardens by Harlan P. Kelsey in 1895 and later repeatedly reintroduced from its native habitat.

Forsythia ovata Nakai in Bot. Mag. xxxı. 104 (1917); Fl. Sylv. Kor. x. 20, t. 3 (1921).

Descriptioni adde: Ramuli hornotini maturi cinereo-flavidi vel flavescentes, sparse lenticellati, secundo anno cinerascentes vel cinerei, cortice 
tertio vel quarto anno leviter suberoso et rimis longitudinalibus fisso; medulla septata. Flores solitarii, brevissime pedicellati pedicello toto perulis abscondito; sepala late ovata, apice rotundata, medium corollae tubum aequantia, $2.5 \mathrm{~mm}$. longa; corolla succinea ("amber yellow" ex Ridgway, Color Stand. pl. xvi. 21'b), tubo lato $5 \mathrm{~mm}$. longo intus striis 12 aurantiacis notato, lobis late oblongis $11-12 \mathrm{~mm}$. longis $5-6 \mathrm{~mm}$. latis apice rotundatis vel leviter truncatis; stamina in planta visa microstyla tubum corollae paullo superantia.

Plants raised from seed collected by E. H. Wilson in Korea in 1917 flowered this spring for the first time in this Arboretum. As the flowers have not been described, a description drawn up from the living material is here given. Forsythia ovata appears to be a very distinct species; even in its winter state it is easily distinguished from the other species by the pale yellow color of the young branchlets and by the light gray bark of the older branchlets which become slightly corky and split by longitudinal fissures.

Viburnum corymbosum Rehder in Jour. Arnold Arb. IIr. 214 (December 28, 1922) is antedated by $V$. corymbosum Urban in Fedde, Rep. Spec. Nov. xvin. 121 (August 15, 1922). When I published this new combination based on Cassine corymbosa Mill., the August number of Fedde's Repertorium had not yet reached the Arboretum library and I therefore was not aware of the existence of the older homonym. I consider it, however, rather fortunate that the publication of Urban's $V$. corymbosum makes it possible to retain the well-known name $V$. obovatum Walt. for the species in question, for the two other older names enumerated by me (l. c.) are non-valid names and cannot replace Walter's name. The first of these names, Cassine peragua of 1753 (1. c. 213, footnote 3) is a homonym of his earlier and valid Cassine peragua of 1753 (1. c. 213, footnote 3) and Cassine caroliniana Lamarck is not valid, because it is a synonym of the earlier and valid Cassine corymbosa Miller which, however, as already stated cannot be transferred to the genus Viburnum, on account of $V$. corymbosum Urb.

Lonicera subsessilis Rehder in Jour. Arnold Arb. II. 126 (1920); II. 240 (1922).

Lonicera diamantiaca Nakai in Jour. Coll. Sci. Tokyo xLII. 100 (1921).

Descriptioni adde: Frutex ramulis ab initio glabris, plus minusve purpureis vel purpurascentibus; folia juvenilia margine ciliolato et costa media supra minute glandulosa excepiis glabra, supra laete viridia, nitidula, subtus glaucescentia; flores pedunculis ad $3 \mathrm{~mm}$. longis glabris; bracteae triangulari-ovatae, bracteolis breviores, glabrae; bracteolae 2, semiorbiculares, multo latiores quam longae, tertiam partem ovariorum ad medium vel fere ad apicem connatorum aequantes, circiter $1 \mathrm{~mm}$. longae, margine minutissime glanduloso-ciliatae; dentes calycis 4, lanceolati, circiter $1 \mathrm{~mm}$. longi, basi tantum vel vix connati, minute glanduloso-ciliati; corollae dorso contiguae ad directiones oppositas spectantes, profunde 
bilabiatae, $1.2 \mathrm{~mm}$. longae, extus glabrae, initio fere alba vel interdum ad apicem leviter rubescentes, mox flavescentes, leviter fragrantes, tubo $4 \mathrm{~mm}$. longo manifeste gibboso, labio inferiore reflexo, labio superiore erecto intus glabro breviter trilobo lobis rotundato-ovatis concavis circiter $1.5 \mathrm{~mm}$. longis; stamina 4, corollam subaequantia filamentis ad imam basin et ad partem tubo adnatam longe pilosis, tubo cetero intus glabro, antheris lineari-oblongis $3 \mathrm{~mm}$. longis; stylus stamina paullo superans, basin versus densius infra medium sparse et supra medium sparsissime pilosus; ovarium biloculare loculis plerisque 4-ovulatis.

A plant of Lonicera subsessilis raised from seed collected by E. H. Wilson in Korea and received in 1917 flowered this year early in June for the first time in this Arboretum, affording the opportunity to complete the description of this species of which the flowers were before unknown. The species belongs to the division of the subsection Rhodanthae with connate ovaries and red fruit in which $L$. conjugialis Kellogg, L. Tatarinovii Maxim., L. Maximowiczii Reg., L. Chamissoi Bge. and L. Graebneri Rehd. belong and is most closely related to the last which has short peduncles and apparently pale-colored flowers, while the others have long and slender peduncles and dark-colored flowers, but L. Graebneri is easily distinguished by its pubescent leaves, longer peduncles, longer subulate pilose bracts, setosely ciliate bractlets and longer setosely ciliate sepals. A remarkable feature of this species will be its tetramerous flowers if this turns out to be a specific character and not an abnormal state; the fact that not only in the one shrub which flowered here all flowers without exception showed a 3-lobed upper lip and 4 stamens but that also in the type specimen the young fruits show only 4 calyx-lobes, as far as the latter have not fallen off, would indicate that the tetramerous flowers are a specific character. The only other species of the genus which has occasionally tetramerous flowers is L. angustifolia Wall. of the subgenus Isoxylosteum.

$\times$ Lonicera Purpusii (L. fragrantissima $\times$ Standishii), hybr. nov.

Upright shrub: branchlets glabrous, or particularly the longer vigorous shoots, loosely setose-pilose with reflexed hairs, the young shoots not bloomy; leaves elliptic-ovate or ovate to narrow-elliptic or oblong-ovate, 5-8 cm. long, and $2.5-4 \mathrm{~cm}$. broad, acute to acuminate and mucronate, rounded to broadly cuneate at the base or sometimes the lower ones slightly subcordate, dark green and glabrous above, light green and reticulately veined beneath, and setose-pilose on the midrib and sparingly so on the lateral veins and veinlets or, particularly on the flower-bearing branchlets, nearly glabrous; petioles setose to nearly glabrous. Flowers very similar to those of $L$. fragrantissima, glabrous except some hairs on the margin of the bracts.

Specimens examined: Botanic Garden, Darmstadt, Germany, A. Purpus 1920 and 1921 (flowers and mature leaves).

This hybrid originated spontaneously some years ago in the Botanic Garden at Darmstadt from seed of one of the parents. In its leaves it is 


\section{$2 \mathrm{BHL}$ Biodiversity Heritage Library}

Rehder, Alfred. 1921. "New Species, Varieties and Combinations from the Herbarium and the Collections of the Arnold Arboretum." Journal of the Arnold Arboretum 4(4), 246-253. https://doi.org/10.5962/p.324781.

View This Item Online: https://www.biodiversitylibrary.org/item/33584

DOI: https://doi.org/10.5962/p.324781

Permalink: https://www.biodiversitylibrary.org/partpdf/324781

\section{Holding Institution}

Missouri Botanical Garden, Peter H. Raven Library

\section{Sponsored by}

Missouri Botanical Garden

\section{Copyright \& Reuse}

Copyright Status: Public domain. The BHL considers that this work is no longer under copyright protection.

This document was created from content at the Biodiversity Heritage Library, the world's largest open access digital library for biodiversity literature and archives. Visit BHL at https://www.biodiversitylibrary.org. 